\title{
Study on Exchangeable Cation Determining Base Saturation Percentage of Soil in South China
}

\author{
Anqi Wang1,2, Xiangzhen Kong1, Xiaodong Song1, Bing Ju¹, Decheng Li ${ }^{*}$ \\ ${ }^{1}$ State Key Laboratory of Soil and Sustainable Agriculture, Institute of Soil Science, Chinese Academy of Sciences, Nanjing, China \\ ${ }^{2}$ University of the Chinese Academy of Sciences, Beijing, China \\ Email: aqwang@issas.ac.cn, ${ }^{*}$ dcli@issas.ac.cn
}

How to cite this paper: Wang, A.Q., Kong, X.Z., Song, X.D., Ju, B. and Li, D.C. (2020) Study on Exchangeable Cation Determining Base Saturation Percentage of Soil in South China. Agricultural Sciences, 11, $17-26$.

https://doi.org/10.4236/as.2020.111002

Received: November 26, 2019

Accepted: December 30, 2019

Published: January 2, 2020

Copyright $\odot 2020$ by author(s) and Scientific Research Publishing Inc. This work is licensed under the Creative Commons Attribution International License (CC BY 4.0).

http://creativecommons.org/licenses/by/4.0/

\begin{abstract}
Base saturation percentage (BSP) is an important soil chemical index in soil fertility and soil taxonomy. However, it is still unclear what exchangeable cation dominates BSP of soil in south China. Therefore, in this study, the data of BSPs and exchangeable $\mathrm{H}^{+}, \mathrm{Al}^{3+}, \mathrm{Ca}^{2+}, \mathrm{Mg}^{2+}, \mathrm{K}^{+}$and $\mathrm{Na}^{+}$of 109 and 45 horizon samples of 50 and 28 soil species in red soil and yellow soil groups in the Database of Chinese Soil Species were used to explore further the characteristics of BSPs and exchangeable cations as well as the correlation between BSPs and exchangeable cations. The results showed that the concentrations of exchangeable cations in both red soil and yellow soil groups were in an order of $\mathrm{Al}^{3+}(4.55 \pm 1.47$ and $4.22 \pm 1.2 \mathrm{cmol}(+) / \mathrm{kg})>\mathrm{Ca}^{2+}(0.32 \pm 0.21$ and $0.36 \pm$ $0.24 \mathrm{cmol}(+) / \mathrm{kg})>\mathrm{H}^{+}(0.23 \pm 0.13$ and $0.19 \pm 0.10 \mathrm{cmol}(+) / \mathrm{kg})>\mathrm{K}^{+}(0.16 \pm$ 0.09 and $0.16 \pm 0.11 \mathrm{cmol}(+) / \mathrm{kg})>\mathrm{Mg}^{2+}(0.13 \pm 0.09$ and $0.11 \pm 0.08$ $\mathrm{cmol}(+) / \mathrm{kg})>\mathrm{Na}^{+}(0.08 \pm 0.06$ and $0.11 \pm 0.06 \mathrm{cmol}(+) / \mathrm{kg})$. For red soil group, $\mathrm{Al}^{3+}$ concentration was significantly higher than those of other exchangeable cations, $\mathrm{Ca}^{2+}$ and $\mathrm{H}^{+}$concentrations were significantly higher than those of $\mathrm{K}^{+}, \mathrm{Mg}^{2+}$ and $\mathrm{Na}^{+}$; while for yellow soil group, $\mathrm{Ca}^{2+}, \mathrm{H}^{+}$and $\mathrm{K}^{+}$concentrations were significantly higher than those of $\mathrm{Mg}^{2+}$ and $\mathrm{K}^{+}$. BSP of red soil group was codetermined by $\mathrm{Ca}^{2+}, \mathrm{Al}^{3+}, \mathrm{Mg}^{2+}$ and $\mathrm{Na}^{+}$, with the contributions of $33.81 \%, 19.82 \%$ and $14.49 \%$, respectively; while BSP of yellow soil group was codetermined by $\mathrm{Al}^{3+}, \mathrm{Ca}^{2+}, \mathrm{Mg}^{2+}, \mathrm{K}^{+}$and $\mathrm{Na}^{+}$, with the contributions of $24.91 \%, 21.55 \%, 19.91 \%$ and $14.21 \%$, respectively. A higher concentration of exchangeable cation does not mean the higher importance of the cation to soil BSP.
\end{abstract}

\section{Keywords}

Base Saturation Percentage (BSP), Exchangeable Cations, Correlation, Red Soil, Yellow Soil, South China 


\section{Introduction}

Base saturation percentage (BSP) is an important soil chemical index which has implication not only in soil fertility [1] [2] [3] but also in soil taxonomy [4] [5]. Existing studies have pointed out that BSP could be affected by climatic, geochemical, and environmental conditions, such as acid rain and dust deposition, waterlogging condition, $\mathrm{pH}$, nitrogen application, organic matter and clay contents, cation exchange capacity and so on [6], but these studied factors mainly are external or indirect factors. As defined as the sum of exchangeable $\mathrm{Ca}^{2+}$, $\mathrm{Mg}^{2+}, \mathrm{K}^{+}$, and $\mathrm{Na}^{+}$relative to total soil cation exchange capacity (CEC) at $\mathrm{pH} 7.0$ or 8.2 [7] [8], BSP is conceptually affected simultaneously by $\mathrm{Ca}^{2+}, \mathrm{Mg}^{2+}, \mathrm{K}^{+}, \mathrm{Na}^{+}$, $\mathrm{Al}^{3+}$ and $\mathrm{H}^{+}$. Some studies found that BSP was dominated by $\mathrm{Ca}^{2+}$ for the calcareous soils on a small orchard scale [9] [10], but no consideration was given to the importance of different exchangeable cations to BSPs.

Red soil and yellow soil groups (in Chinese Genetic Classification) are two important zonal soil groups widely distributed in the hilly area of tropical and subtropical south China which are characterized by high desilicification but fersialitization [11] [12]. There are 133 and 76 soil species in red soil and yellow soil groups, respectively, which were derived under diverse climate conditions, parent materials and land use types [13]. However, it is still unclear that what exchangeable cations dominate BSPs of red soil and yellow soil groups; therefore, the objective of our study is to understand further the characteristics of BSPs and exchangeable cations, and to quantitatively analyze the importance of different exchangeable cations to BSPs of red soil and yellow soil groups.

\section{Methods and Materials}

\subsection{Data Sources}

The data of BSPs and exchangeable cation concentrations $\left(\mathrm{H}^{+}, \mathrm{Al}^{3+}, \mathrm{Ca}^{2+}, \mathrm{Mg}^{2+}\right.$, $\mathrm{K}^{+}$and $\mathrm{Na}^{+}$) are from Chinese Soil Database (http://vdb3.soil.csdb.cn/). After the comparison of data completeness and the elimination of abnormal data by the method of $\mu \pm 3 \sigma, 136$ and 58 horizon samples from 59 and 28 soil species in red soil and yellow soil groups in South China were adopted, respectively (see Figure 1), here, the spatial location of the selected soil species in Figure were roughly determined according to the information of site description of the typical soil profiles in the available literatures [13]. Other main soil groups such as latosol and latosolic red soil groups were not considered due to the insufficient typical profiles (less than 8 soil profiles) after the elimination of abnormal data of BSPs and exchangeable cations.

\subsection{Sampling and Measurement of Soil Samples}

According to the available historical records, the sampling and measurement of soil samples were as follows: 1) the location of each typical soil profile was mainly decided by the comprehensive consideration of the representation of topography, parent material, land use type, and etc.; 2) a standard soil profile 


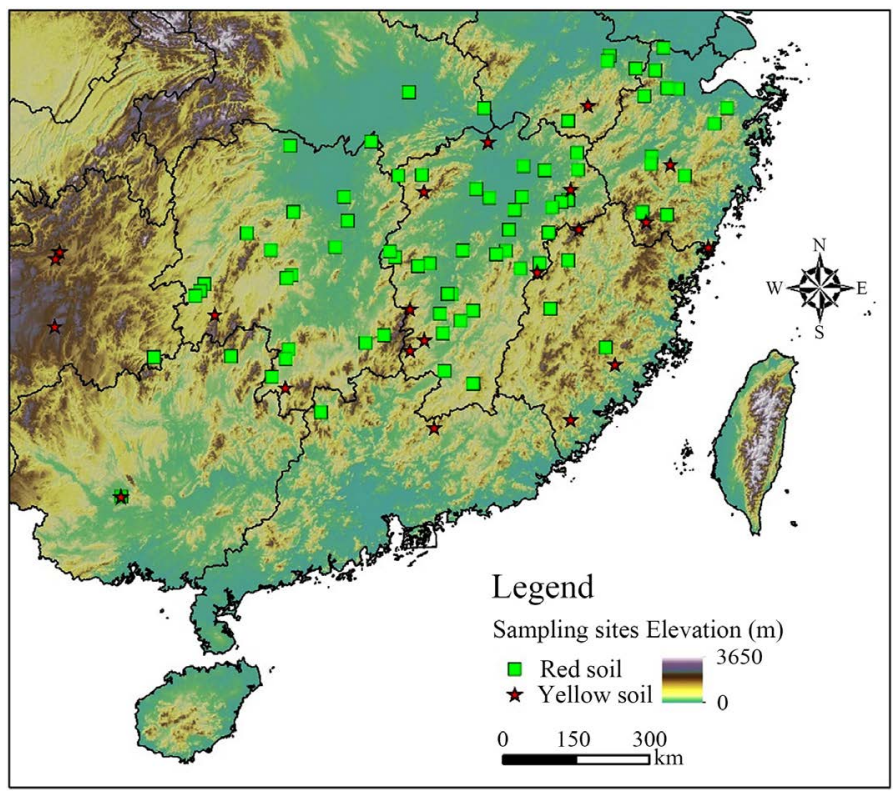

Figure 1. Spatial distribution of adopted soil profiles of red soil and yellow soil groups.

(1.0 $\mathrm{m}$ in width and $1.2-1.5 \mathrm{~m}$ in depth) was excavated; 3 ) the horizons were decided according to morphological characteristics of profile; 4) soil sample was collected uniformly within each horizon, and $2 \mathrm{~kg}$ of soil was kept left by using quartering and kept in the cloth bag. In the lab, soil samples were air dried, and the impurities of roots and gravels were removed. Then they were grinded to pass $1.7 \mathrm{~mm}, 0.25 \mathrm{~mm}$ and $0.149 \mathrm{~mm}$ sieves respectively.

Exchangeable $\mathrm{K}^{+}$and $\mathrm{Na}^{+}$were determined by flame photometer method, $\mathrm{Ca}^{2+}$ and $\mathrm{Mg}^{2+}$ determined by the method of EDTA volumetric method, $\mathrm{H}^{+}$and $\mathrm{Al}^{3+}$ were determined by titration method after $1 \mathrm{~mol} / \mathrm{L} \mathrm{KCl}$ extraction, total amount of base exchangeable cations determined by the method of evaporation and neutralization titration after $1 \mathrm{~mol} / \mathrm{L} \mathrm{NH}_{4} \mathrm{OAc}(\mathrm{pH} 7.0)$ extraction, cation exchange capacity (CEC) determined by the method of $1 \mathrm{~mol} / \mathrm{L} \mathrm{NH}_{4} \mathrm{OAc}$ exchange [8] [14] [15].

\subsection{Data Processing, Modeling and Mapping}

Microsoft Excel 2016 and IBM Statistics SPSS 20.0 were used for data processing, correlation modeling and mapping, difference significance of exchangeable cations and BSPs were tested by LSD method of one-way ANOVA, Pearson correlation (2-tailed) was used to describe the correlation between exchangeable cations and BSP [16] [17]. The contributions of exchangeable cations to BSP is calculated as follows: by using SPSS, the data of exchangeable cations and BSP were normalized, the multiple linear regression model between BSP and exchangeable cations was obtained, and then the percentage of the coefficient of $i$ cation to total sum of the coefficients of all exchangeable cations in the model was calculated as the contribution of $i$ cation to BSP [18]. Here, principle com- 
ponent analysis was not used to do so is because we want to quantitatively know the contribution of each cation to BSP.

\section{Results and Discussions}

\subsection{Statistical Information of Exchangeable Cations and BSPs}

Table 1 gives the statistical information of exchangeable cations and BSPs of red soil and yellow soil groups. It can be seen from Table 1 that except $\mathrm{Na}^{+}$, there were no significant differences in other exchangeable cations between red soil and yellow soil groups $(\mathrm{p}<0.05)$. BSP of yellow soil group was significantly higher than that of red soil group $(\mathrm{p}<0.05)$. cation concentrations of both red soil and yellow soil groups were in an order of $\mathrm{Al}^{3+}>\mathrm{Ca}^{2+}>\mathrm{H}^{+}>\mathrm{K}^{+}>\mathrm{Mg}^{2+}>\mathrm{Na}^{+}$, in which $\mathrm{Al}^{3+}$ was significantly higher than all other exchangeable cations. For red soil group, $\mathrm{Ca}^{2+}$ and $\mathrm{H}^{+}$were significantly higher than $\mathrm{K}^{+}, \mathrm{Mg}^{2+}$ and $\mathrm{Na}^{+}$, but no significant difference between $\mathrm{Mg}^{2+}, \mathrm{K}^{+}$and $\mathrm{Na}^{+}$. For yellow soil group, $\mathrm{Ca}^{2+}$ was significantly higher than $\mathrm{Mg}^{2+}, \mathrm{K}^{+}$and $\mathrm{Na}^{+}$, but no significant difference between $\mathrm{H}^{+}, \mathrm{Mg}^{2+}, \mathrm{K}^{+}$and $\mathrm{Na}^{+}$. 4) All exchangeable cations and BSPs of red soil and yellow soil groups were in moderate variation (coefficient of variation $<100 \%$ ) and in positive skew distribution (skewness $>0$ ), while their probability density curves of all exchangeable cations and BSPs were near very flat (kurtosis $=0$ ) or flat $(0<$ kurtosis $<0.67)$ [16] [17].

\subsection{Correlations between BSPs and Exchangeable Cations}

For the correlation between BSP with exchangeable cations, it can be seen from Table 2 that, 1$)$ for red soil group, BSP had notable correlation $(\mathrm{R}=0.5-0.8$, the same below) with $\mathrm{Ca}^{2+}, \mathrm{Mg}^{2+}$ and $\mathrm{Al}^{3+}$ while low correlation $(\mathrm{R}=0.3-0.5$, the same below) with $\mathrm{Na}^{+}$for red soil group; 2) for yellow soil group, BSP had notable correlation with $\mathrm{Ca}^{2+}$ and $\mathrm{Al}^{3+}$ while low correlation with $\mathrm{Na}^{+}, \mathrm{Mg}^{2+}$ and $\mathrm{K}^{+}$; 3) low correlation were found between $\mathrm{H}^{+}$with $\mathrm{Al}^{3+}, \mathrm{Ca}^{2+}$ with $\mathrm{Mg}^{2+}$ and $\mathrm{Na}^{+}$in both soil groups and between $\mathrm{Mg}^{2+}$ with $\mathrm{K}^{+}$and $\mathrm{Na}^{+}$in yellow soil group.

Table 1. Statistical information of exchangeable cations and BSPs of red soil and yellow soil groups.

\begin{tabular}{|c|c|c|c|c|c|c|c|c|}
\hline \multirow{2}{*}{ Ion } & \multicolumn{4}{|c|}{ Red soil group $(\mathrm{n}=109)$} & \multicolumn{4}{|c|}{ Yellow soil group $(n=45)$} \\
\hline & Mean \pm Std.D & C.V. (\%) & Skewness & Kurtosis & Mean \pm Std.D & C.V. (\%) & Skewness & Kurtosis \\
\hline $\mathrm{H}^{+}$ & $0.23 \pm 0.13 b$ & 58.44 & 0.71 & -0.38 & $0.19 \pm 0.10 b c$ & 52.58 & 0.37 & -0.79 \\
\hline $\mathrm{Al}^{3+}$ & $4.55 \pm 1.47 \mathrm{a}$ & 32.26 & 0.53 & 0.46 & $4.22 \pm 1.24 \mathrm{a}$ & 29.35 & 0.20 & -0.46 \\
\hline $\mathrm{Ca}^{2+}$ & $0.32 \pm 0.21 b$ & 65.63 & 0.93 & 0.27 & $0.36 \pm 0.24 b$ & 66.28 & 0.92 & 0.11 \\
\hline $\mathrm{Mg}^{2+}$ & $0.13 \pm 0.09 c$ & 68.12 & 0.64 & -0.28 & $0.11 \pm 0.08 c$ & 68.12 & 0.59 & 0.06 \\
\hline $\mathrm{K}^{+}$ & $0.16 \pm 0.09 c$ & 56.85 & 0.83 & 0.42 & $0.16 \pm 0.11 c$ & 65.78 & 0.37 & -0.97 \\
\hline $\mathrm{Na}^{+}$ & $0.08 \pm 0.06 c$ & 79.53 & 0.63 & -0.46 & $0.11 \pm 0.06 c$ & 54.23 & 0.82 & -0.33 \\
\hline BSP & $13.26 \pm 5.85 B$ & 44.16 & 0.30 & -0.81 & $16.03 \pm 7.87 \mathrm{~A}$ & 49.11 & 0.40 & -0.40 \\
\hline
\end{tabular}

*. Different lowercase letters in the same columns show mean difference of exchangeable cations is significant at the 0.05 level, and different capital letters in BSP line show mean difference of BSPs is significant at the 0.05 level. 
Table 2. Pearson correlation coefficients (R) between exchangeable cations and BSPs.

\begin{tabular}{|c|c|c|c|c|c|c|c|}
\hline Soil group & Parameter & $\mathrm{H}^{+}$ & $\mathrm{Al}^{3+}$ & $\mathrm{Ca}^{2+}$ & $\mathrm{Mg}^{2+}$ & $\mathrm{K}^{+}$ & $\mathrm{Na}^{+}$ \\
\hline \multirow{7}{*}{$\begin{array}{l}\text { Red soil } \\
(\mathrm{n}=109)\end{array}$} & $\mathrm{H}^{+}$ & 1 & & & & & \\
\hline & $\mathrm{Al}^{3+}$ & $0.219^{*}$ & 1 & & & & \\
\hline & $\mathrm{Ca}^{2+}$ & 0.081 & 0.002 & 1 & & & \\
\hline & $\mathrm{Mg}^{2+}$ & 0.046 & 0.043 & $0.420^{* *}$ & 1 & & \\
\hline & $\mathrm{K}^{+}$ & 0.164 & 0.120 & 0.062 & $0.310^{* *}$ & 1 & \\
\hline & $\mathrm{Na}^{+}$ & 0.104 & 0.019 & $0.364^{* *}$ & $0.314^{* *}$ & -0.095 & 1 \\
\hline & BSP & -0.074 & $-0.504^{* *}$ & $0.668^{* *}$ & $0.555^{* *}$ & 0.170 & $0.455^{* *}$ \\
\hline \multirow{7}{*}{$\begin{array}{l}\text { Yellow soil } \\
\quad(\mathrm{n}=45)\end{array}$} & $\mathrm{H}^{+}$ & 1 & & & & & \\
\hline & $\mathrm{Al}^{3+}$ & $0.351^{* *}$ & 1 & & & & \\
\hline & $\mathrm{Ca}^{2+}$ & 0.073 & 0.028 & 1 & & & \\
\hline & $\mathrm{Mg}^{2+}$ & -0.119 & 0.024 & $0.305^{*}$ & 1 & & \\
\hline & $\mathrm{K}^{+}$ & 0.147 & -0.007 & 0.222 & 0.079 & 1 & \\
\hline & $\mathrm{Na}^{+}$ & -0.057 & -0.149 & $0.408^{* *}$ & 0.125 & 0.076 & 1 \\
\hline & BSP & -0.221 & $-0.526^{* *}$ & $0.598^{* *}$ & $0.457^{* *}$ & $0.300^{*}$ & $0.461^{* *}$ \\
\hline
\end{tabular}

** and ${ }^{*}$ Correlation are significant at the 0.01 and 0.05 levels (2-tailed).

Table 3 lists the optimal correlation models between BSPs with exchangeable cations and the multiple linear regression models between BSPs and exchangeable cations, it shows that most of the optimal models are in a quadratic pattern.

Table 4 shows the calculated importance of exchangeable cations to BSPs with the Random Forest Package, it can be seen from Table 4 that, 1) the importance of $\mathrm{H}^{+}$and $\mathrm{K}^{+}$of red soil were not significant to BSP, while only that of $\mathrm{H}^{+}$not significant for yellow soil; 2) the orders of BSPs and the importance of the top three exchangeable cations to BSPs were different between red soil and yellow soil groups, which was $\mathrm{Ca}^{2+}(33.81 \%)>\mathrm{Al}^{3+}(29.87 \%)>\mathrm{Mg}^{2+}(22.28 \%)$ for red soil, while $\mathrm{Al}^{3+}(24.91 \%)>\mathrm{Ca}^{2+}(21.55 \%)>\mathrm{Mg}^{2+}$ (19.91\%) for yellow soil; 3) although generally the importance of $\mathrm{Ca}^{2+}, \mathrm{Al}^{3+}$ and $\mathrm{Mg}^{2+}$ to soil BSPs are greater due to their high concentrations, no significant correlation was found between cation concentrations and their importance to BSPs if all exchangeable cations are considered.

\subsection{Discussion}

Some studies already proved and explained that $\mathrm{Al}^{3+}$ was the main form in exchangeable acid exchangeable cations in soils of south China [19] [20] [21] [22]. Our data also showed $\mathrm{Al}^{3+}$ were the highest in all exchangeable cations both in red soil and yellow soil groups, which is common in soils of south China due to intensive desilicification but fersialitization caused by high temperature and precipitation [11] [12] [13], so it is normal for $\mathrm{Al}^{3+}$ as one of the important exchangeable cations controlling BSPs of red soil and yellow soil groups in south China. 
Table 3. Optimal correlation models between BSPs with exchangeable cations of red soil and yellow soil groups.

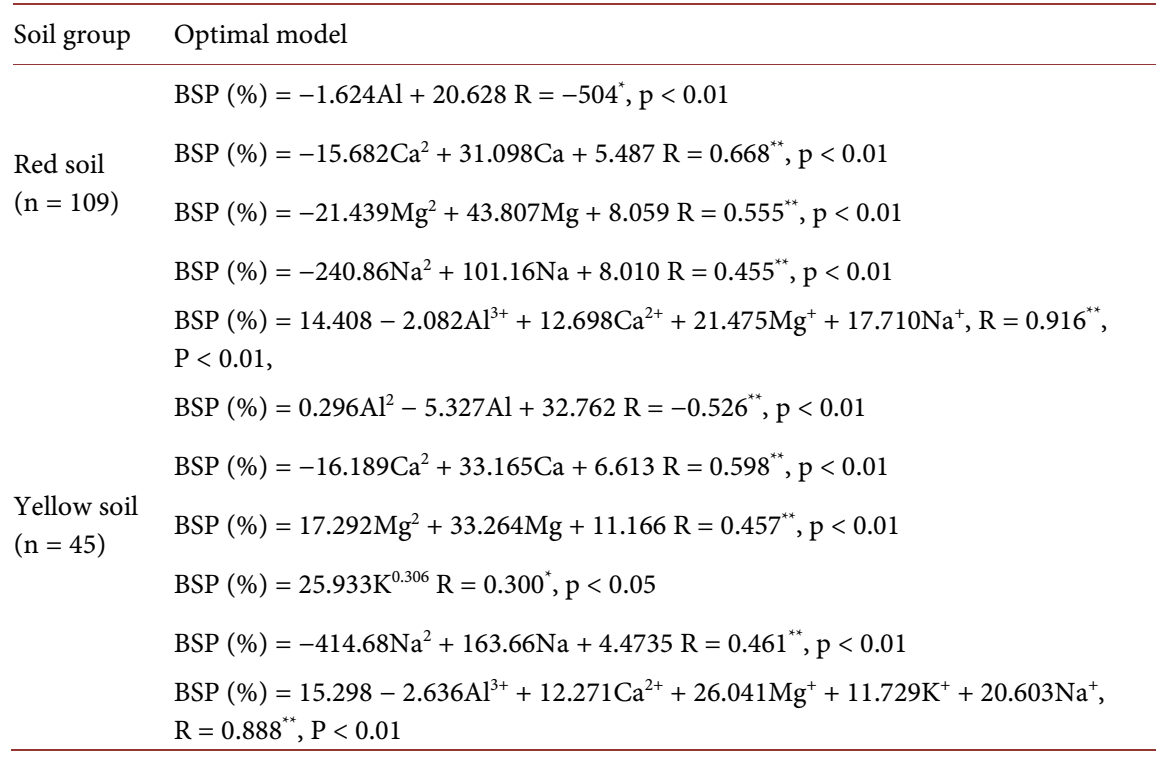

Table 4. Importance of exchangeable cations to BSPs in red soil and yellow soil groups.

\begin{tabular}{cccccccc}
\hline & \multicolumn{5}{c}{ Red soil group } & \multicolumn{5}{c}{ Yellow soil group } \\
\hline Cation & Importance Norm. importance & Sig. & Cation & Importance & Norm. importance & Cation \\
\hline $\mathrm{Ca}^{2+}$ & 38.00 & 33.81 & $0.02^{*}$ & $\mathrm{Al}^{3+}$ & 18.47 & 24.91 & $0.02^{*}$ \\
$\mathrm{Al}^{3+}$ & 29.87 & 26.58 & $0.02^{*}$ & $\mathrm{Ca}^{2+}$ & 15.98 & 21.55 & $0.02^{*}$ \\
$\mathrm{Mg}^{2+}$ & 22.28 & 19.82 & $0.02^{*}$ & $\mathrm{Mg}^{2+}$ & 14.76 & 19.91 & $0.02^{*}$ \\
$\mathrm{Na}^{+}$ & 16.28 & 14.49 & $0.02^{*}$ & $\mathrm{~K}^{+}$ & 10.56 & 14.24 & $0.04^{*}$ \\
$\mathrm{~K}^{+}$ & 3.03 & 2.70 & 0.29 & $\mathrm{Na}^{+}$ & 10.54 & 14.21 & $0.02^{*}$ \\
$\mathrm{H}^{+}$ & 2.93 & 2.61 & 0.21 & $\mathrm{H}^{+}$ & 3.84 & 5.18 & 0.18 \\
\hline
\end{tabular}

* Importance is significant at 0.05 level; Norm. means normalized.

The lower concentrations of base exchangeable cations compared with $\mathrm{Al}^{3+}$ could be attributed to the heavy leaching losses of base exchangeable cations, which were higher than $80 \%$ [23] [24], due to the high temperature and precipitation in south China (annual temperature and precipitation as $16^{\circ} \mathrm{C}-25^{\circ} \mathrm{C}$ and 800 - $2000 \mathrm{~mm}$, dryness less than 1.0).

A significant difference was found in BSPs between red soil group and yellow soil groups, which could be attributed to the accumulation effects in the differences of the sums of acid exchangeable cations and base exchangeable cations between the two soil groups. It could be found that although there was significant difference in exchangeable cations, the sums of acid exchangeable cations and base exchangeable cations, the sum of acid exchangeable cations of red soil $(4.77 \pm 1.50 \mathrm{cmol}(+) / \mathrm{kg})$ was higher than that of yellow soil group $(4.41 \pm 1.27$ $\mathrm{cmol}(+) / \mathrm{kg})$, while the sum of base exchangeable cations of red soil group $(0.69 \pm 0.32 \mathrm{cmol}(+) / \mathrm{kg})$ was lower than that of yellow soil group $(0.74 \pm 0.35$ 
$\mathrm{cmol}(+) / \mathrm{kg}$ ). Generally speaking, red soil group was formed and evolved in the environment with higher temperature and precipitation $\left(15^{\circ} \mathrm{C}-25^{\circ} \mathrm{C}\right.$ in annual mean temperature and $1200-2500 \mathrm{~mm}$ in annual precipitation) compared to yellow soil group $\left(14^{\circ} \mathrm{C}-19^{\circ} \mathrm{C}\right.$ in annual mean temperature and $1000-2000 \mathrm{~mm}$ in annual precipitation), which resulted in higher acid exchangeable cations and lower base exchangeable cations of red soil group compared with yellow soil group [11] [12] [13].

Some studies found that BSP was dominated by $\mathrm{Ca}^{2+}$ in calcareous soil species on a small orchard scale due to the highest concentration of $\mathrm{Ca}^{2+}$ derived from the calcareous parent material [9] [10], but didn't give information on the importance of exchangeable cations to BSPs. In contrast, our study not only found further that cation concentrations were in order of $\mathrm{Al}^{3+}>\mathrm{Ca}^{2+}>\mathrm{H}^{+}>\mathrm{K}^{+}>$ $\mathrm{Mg}^{2+}>\mathrm{Na}^{+}$both in red soil and yellow soil groups (see Table 1), but also disclosed the importance of exchangeable cations to BSPs, for examples, the importance order of exchangeable cations to BSPs were $\mathrm{Ca}^{2+}(33.81 \%)>\mathrm{Al}^{3+}$ $(26.58 \%)>\mathrm{Mg}^{2+}(19.82 \%)>\mathrm{Na}^{+}(14.49 \%)>\mathrm{K}^{+}(2.70 \%)>\mathrm{H}^{+}(2.61 \%)$ for red soil group while $\mathrm{Al}^{3+}(24.91 \%)>\mathrm{Ca}^{2+}(21.55 \%)>\mathrm{Mg}^{2+}(19.91 \%)>\mathrm{K}^{+}(14.24 \%)>\mathrm{Na}^{+}$ $(14.21 \%)>\mathrm{H}^{+}(5.18 \%)$ for yellow soil group. However, our study shows that exchangeable cations controlling BSPs are different between red soil and yellow soil groups, we think such a complexity is normal because our study includes 59 and 28 soil species of red soil and yellow groups, respectively, which are widely distributed in south China with various soil forming environments and evolution degrees [11] [12] [13]. For examples, the spans of annual temperature and precipitation were $15^{\circ} \mathrm{C}-25^{\circ} \mathrm{C}$ and $1200-2500 \mathrm{~mm}$ for red soil while $14^{\circ} \mathrm{C}$ $19^{\circ} \mathrm{C}$ and $1000-2000$ for yellow soil, respectively [11] [12], meanwhile, the parent materials include granite, sandstone, quaternary red clay, pelite, quartzite, tuff, basalt, shallow-sea sediment, andesite and limestone, etc. and the land use types include dryland, forest, orchard, shrub, grassland, etc. (see Table 5 and Table 6, only main parent materials and land use types presented in the tables),

Table 5. Statistical information of exchangeable cations concentrations and BSPs of soils derived from different parent materials.

\begin{tabular}{cccccc}
\hline Cation & $\begin{array}{c}\text { Granite } \\
(\mathrm{n}=51)\end{array}$ & $\begin{array}{c}\text { Sandstone } \\
(\mathrm{n}=38)\end{array}$ & $\begin{array}{c}\mathrm{Q}_{4} \text { red clay } \\
(\mathrm{n}=22)\end{array}$ & $\begin{array}{c}\text { Pelite } \\
(\mathrm{n}=22)\end{array}$ & $\begin{array}{c}\text { Quartzite } \\
(\mathrm{n}=21)\end{array}$ \\
\hline $\mathrm{H}^{+}$ & $0.20 \pm 0.11 \mathrm{bc}$ & $0.22 \pm 0.13 \mathrm{ab}$ & $0.20 \pm 0.14 \mathrm{ab}$ & $0.27 \pm 0.14 \mathrm{a}$ & $0.22 \pm 0.10 \mathrm{ab}$ \\
$\mathrm{Al}^{3+}$ & $4.65 \pm 1.44 \mathrm{ab}$ & $4.45 \pm 1.66 \mathrm{ab}$ & $4.95 \pm 1.13 \mathrm{a}$ & $3.96 \pm 1.06 \mathrm{bc}$ & $3.99 \pm 1.23 \mathrm{bc}$ \\
$\mathrm{Ca}^{2+}$ & $0.30 \pm 0.22 \mathrm{a}$ & $0.36 \pm 0.21 \mathrm{a}$ & $0.37 \pm 0.26 \mathrm{a}$ & $0.32 \pm 0.23 \mathrm{a}$ & $0.36 \pm 0.20 \mathrm{a}$ \\
$\mathrm{Mg}^{2+}$ & $0.13 \pm 0.08 \mathrm{a}$ & $0.12 \pm 0.09 \mathrm{a}$ & $0.12 \pm 0.10 \mathrm{a}$ & $0.14 \pm 0.08 \mathrm{a}$ & $0.12 \pm 0.09 \mathrm{a}$ \\
$\mathrm{K}^{+}$ & $0.20 \pm 0.10 \mathrm{a}$ & $0.10 \pm 0.05 \mathrm{c}$ & $0.15 \pm 0.08 \mathrm{~b}$ & $0.21 \pm 0.09 \mathrm{a}$ & $0.12 \pm 0.08 \mathrm{bc}$ \\
$\mathrm{Na}^{+}$ & $0.09 \pm 0.06 \mathrm{a}$ & $0.12 \pm 0.07 \mathrm{a}$ & $0.07 \pm 0.06 \mathrm{~b}$ & $0.07 \pm 0.04 \mathrm{~b}$ & $0.09 \pm 0.06 \mathrm{a}$ \\
$\mathrm{BSP}(\%)$ & $14.10 \pm 7.07 \mathrm{a}$ & $13.54 \pm 6.02 \mathrm{a}$ & $12.49 \pm 4.72 \mathrm{a}$ & $15.44 \pm 6.92 \mathrm{a}$ & $15.17 \pm 7.83 \mathrm{a}$ \\
\hline
\end{tabular}

*. Different lowercase letters in the same lines show mean difference is significant at the 0.05 level. Not included soil species with unclear information in parent materials or with the less numbers of profiles. 
Table 6. Statistical information of exchangeable cations concentrations and BSPs of soils under different land use types.

\begin{tabular}{ccccc}
\hline Cation & $\begin{array}{c}\text { Dryland } \\
(\mathrm{n}=30)\end{array}$ & $\begin{array}{c}\text { Forest } \\
(\mathrm{n}=103)\end{array}$ & $\begin{array}{c}\text { Orchard } \\
(\mathrm{n}=7)\end{array}$ & $\begin{array}{c}\text { Shrub\&grass } \\
(\mathrm{n}=7)\end{array}$ \\
\hline $\mathrm{H}^{+}$ & $0.21 \pm 0.13 \mathrm{a}$ & $0.22 \pm 0.12 \mathrm{a}$ & $0.18 \pm 0.10 \mathrm{a}$ & $0.24 \pm 0.15 \mathrm{a}$ \\
$\mathrm{Al}^{3+}$ & $4.12 \pm 1.59 \mathrm{c}$ & $4.41 \pm 1.36 \mathrm{c}$ & $4.57 \pm 1.00 \mathrm{ab}$ & $5.43 \pm 1.23 \mathrm{a}$ \\
$\mathrm{Ca}^{2+}$ & $0.30 \pm 0.21 \mathrm{~b}$ & $0.32 \pm 0.22 \mathrm{~b}$ & $0.52 \pm 0.27 \mathrm{a}$ & $0.47 \pm 0.18 \mathrm{a}$ \\
$\mathrm{Mg}^{2+}$ & $0.15 \pm 0.09 \mathrm{a}$ & $0.12 \pm 0.08 \mathrm{a}$ & $0.15 \pm 0.07 \mathrm{a}$ & $0.11 \pm 0.10 \mathrm{a}$ \\
$\mathrm{K}^{+}$ & $0.13 \pm 0.08 \mathrm{bc}$ & $0.17 \pm 0.09 \mathrm{a}$ & $0.21 \pm 0.13 \mathrm{a}$ & $0.13 \pm 0.10 \mathrm{ab}$ \\
$\mathrm{Na}^{+}$ & $0.10 \pm 0.07 \mathrm{~b}$ & $0.08 \pm 0.06 \mathrm{~b}$ & $0.05 \pm 0.03 \mathrm{~b}$ & $0.15 \pm 0.07 \mathrm{a}$ \\
$\mathrm{BSP}(\%)$ & $14.68 \pm 7.09 \mathrm{a}$ & $13.80 \pm 6.82 \mathrm{a}$ & $16.32 \pm 2.78 \mathrm{a}$ & $13.59 \pm 5.33 \mathrm{a}$ \\
\hline
\end{tabular}

*. Different lowercase letters in the same lines show mean difference is significant at the 0.05 level. Soil species with unclear information in land use types were omitted in this study.

and it can be seen from Table 5 and Table 6 that $\mathrm{Al}^{3+}, \mathrm{Ca}^{2+}$ and $\mathrm{H}^{+}$are the top three exchangeable cations in concentrations not only in different parent materials but also in different land use types, and there are certain differences in cation concentrations but no significant difference in BSPs between different parent materials or different land use types.

However, there are still some problems left to be solved in our study, for examples, why $\mathrm{H}^{+}$is not significantly important to BSP with a higher concentration than $\mathrm{K}^{+}, \mathrm{Mg}^{2+}$ and $\mathrm{Na}^{+}$? Why $\mathrm{K}^{+}$is significantly important to BSP of yellow soil group but not to red soil group?

\section{Conclusion}

By using the data of BSPs and cation concentrations of soil species of red soil and yellow soil groups in south China, our study disclosed that the concentrations of exchangeable cations in both red soil and yellow soil groups were in an order of $\mathrm{Al}^{3+}>\mathrm{Ca}^{2+}>\mathrm{H}^{+}>\mathrm{K}^{+}>\mathrm{Mg}^{2+}>\mathrm{Na}^{+}$. BSP of red soil group was codetermined by $\mathrm{Ca}^{2+}, \mathrm{Al}^{3+}, \mathrm{Mg}^{2+}$ and $\mathrm{Na}^{+}$, while $\mathrm{BSP}$ of yellow soil group by $\mathrm{Al}^{3+}, \mathrm{Ca}^{2+}$, $\mathrm{Mg}^{2+}, \mathrm{K}^{+}$and $\mathrm{Na}^{+}$. But no significant correlation was found between cation concentration and importance of cation to soil BSP if all exchangeable cations are considered.

\section{Acknowledgements}

This study was supported by projects of the National Natural Science Foundation of China (Grant No. 41877008) and the National S\&T Basic Special Foundation Project (No. 2014FY110200). We would like to express thanks to the contribution of all the participants in the data preparation and processing.

\section{Conflicts of Interest}

The authors declare no conflicts of interest regarding the publication of this paper. 


\section{References}

[1] Campo, J., Maass, J.M., Jaramillo, V.J. and Martínez Yrízar, A. (2000) Calcium, Potassium, and Magnesium Cycling in a Mexican Tropical Dry Forest Ecosystem. Biogeochemistry, 49, 21-36. https://doi.org/10.1023/A:1006207319622

[2] Huang, C.Y. (2000) Pedology. China Agriculture Press, Beijing. (In Chinese)

[3] Jobbagy, E.G. and Jackson, R.B. (2001) The Distribution of Soil Nutrients with Depth: Global Patterns and the Imprint of Plants. Biogeochemistry, 53, 51-77. https://doi.org/10.1023/A:1010760720215

[4] Soil Survey Staff (1999) Soil Taxonomy. In: USDA-NRCS, Agricultural Handbook, 2nd Edition, U.S. Government Publishing Office, Washington DC, 436.

[5] CRG-CST (2001) Chinese Soil Taxonomy. Science Press, Beijing, New York.

[6] Osman, K.T. (2012) Soils: Principles, Properties and Management. Springer, Netherlands.

[7] Bohn, H.L., McNeal, B.L. and O'Connor, G.A. (1979) Soil Chemistry. John Wiley and Sons, Toronto, Canada.

[8] Zhang, G.L. and Gong, Z.T. (2012) Soil Survey Laboratory Methods. Science Press, Beijing. (In Chinese)

[9] Mao, H.A., Xie, D.T., Yang, J.H., et al. (2005) Relation of pH and Cation Saturation of Orange Orchard Soil in Chongqing Jiangjin. Chinese Journal of Soil Science, 36, 877-879. (In Chinese).

[10] Li, G.C., Yang, H., Zhang, C.L., et al. (2012) Relation between Soil pH and Base Saturation Percentage under Chinese Chestnut in Typical Karst Region. Soil and Water Conservation in China, No. 8, 49-52. (In Chinese)

[11] Li, Q.K. and Xiong, Y. (1990) Soil of China. 2nd Edition, Science Press, Beijing. (In Chinese)

[12] Chinese Soil Survey Office (1998) Soil of China. China Agriculture Press, Beijing. (In Chinese)

[13] Chinese Soil Survey Office (1993-1995) Chinese Soil Species. China Agriculture Press, Beijing. (In Chinese)

[14] Lu, R.K. (1999) Methods of Soil Agricultural Chemistry Analyses. China Agriculture Press, Beijing. (In Chinese)

[15] Bao, S.D. (2005) Soil Agricultural Chemistry Analyses. China Agriculture Press, Beijing. (In Chinese)

[16] Yu, J.Y. and He, X.X. (2006) Data Statistical Analysis and SPSS Application. Posts \& Telecommuni Exchangeable Cations Press, Beijing. (In Chinese)

[17] Xue, W. (2009) Methods and Appliexchangeable Cations of SPSS Statistical Analysis. Publishing House of Electronics Industry, Beijing (In Chinese)

[18] Sun, G.X., Wang, S., Zhao, C.C., et al. (2009) Contributing Ratio of Impact Factor on Gully Erosion in Loess Hilly and Gully Area of Qinghai Province. Ecology and Environmental Sciences, 18, 1402-1406.

[19] Huang, P.M. (1997) Mechanism of Soil Acidification. In: Dahama, A.K., Ed., Agro's Annual Review of Crop Ecology, Agro Botanica, Bikaner, 79-100.

[20] Yu, T.R. (1997) Chemistry of Variable Charge Soils. Oxford University Press, New York.

[21] Fan, Q.F., Zhang, Y.L., Chen, Z., et al. (2009) Acidity Characteristics and Acidification Mechanism of Soils in Protected Fields. Acta Pedologica Sinica, 46, 466-471. 
(In Chinese)

[22] Xu, R.K. (2015) Research Progresses in Soil Acidification and Its Control. Soils, 47, 238-244. (In Chinese)

[23] Huang, C.M. and Gong, Z.T. (2002) Study on Genesis of Soils Derived from Basalt in Northern Hainan Island III. Element Geochemistry. Acta Pedologica Sinica, 39, 643-652. (In Chinese)

[24] Yang, Y.F., Li, D.C., Zhang, G.L., et al. (2010) Evolution of Chronosequential Soils Derived from Volcanic Basalt on Tropical Leizhou Peninsula, South China. Acta Pedologica Sinica, 47, 817-825. (In Chinese) 